\title{
E-Modul Ekosistem Kearifan Lokal Lampung Barat Berbasis Contextual Teaching And Learning Pada Kelas X SMA
}

\author{
Nukhbatul Bidayati Haka ${ }^{1}$, Ermalia ${ }^{2}$, Fredi Ganda Putra ${ }^{3}$ \\ Pendidikan Biologi, UIN Raden Intan Lampung ${ }^{1,2,3}$ \\ nukhbatulbidayatihaka@ radenintan.ac.id ${ }^{1}$, ermalia862@gmail.com², fredigandaputra@ radenintan.ac.id ${ }^{3}$
}

\begin{abstract}
ABSTRAK
Tujuan penelitian ini adalah untuk mengetahui kelayakan E-modul kearifan lokal Lampung berbasis contextual teaching and learning kelas X mata pelajaran biologi. Penelitian ini termasuk jenis penelitian research and development $(\mathrm{R} \& \mathrm{D})$ yang mengadaptasi dari teori Borg and Gall 7. Subjek penelitian ini ialah pakar bahasa, pakar modul, pakar media, peserta didik kelas $X$ dan guru SMA Negeri 1 Sumberjaya. Teknik pengumpulan data memakai angket, wawancara dan dokumentasi. Teknik analisis data menggunakan statistik deskriptif untuk mengolah data kuantitatif. Hasil penelitian membuktikan E-modul kearifan lokal Lampung berbasis contextual teaching and learning kelas $\mathrm{X}$ mata pelajaran biologi layak digunakan bersumber pada evaluasi mutu E-modul oleh pakar bahasa, pakar modul serta pakar media sebesar 78,7\%, 80\% serta 86\% dengan kriteria totalitas "sangat layak". Saat uji coba secara terbatas mendapatkan respon peserta didik sebesar $85 \%$ sedangkan saat uji coba secara luas mendapatkan respon peserta didik sebesar $86 \%$ dan $88 \%$ serta respon pendidik mata pelajaran biologi sebesar 92\%. Bersumber pada hasil penelitian ini bisa disimpulkan bahwa E-modul kearifan lokal Lampung berbasis contextual teaching and learning kelas X mata pelajaran biologi valid dan praktis untuk digunakan serta dimanfaatkan dalam pembelajaran SMA Negeri 1 Sumberjaya.
\end{abstract}

Kata kunci: Contextual Teaching and Learning, E-modul, Kearifan Lokal

\section{ABSTRACT}

The purpose of this study was to determine the feasibility of the E-module of Lampung local wisdom based on contextual teaching and learning for class $X$ biology subjects. This research is a type of research and development $(R \& D)$ research that adapts the theory of Borg and Gall 7. The subjects of this research are language experts, module experts, media experts, class X students and teachers of SMA Negeri 1 Sumberjaya. Data collection techniques using questionnaires, interviews and documentation. The data analysis technique uses descriptive statistics to process quantitative data. The results of the study prove that the Lampung local wisdom E-module based on contextual teaching and learning class $X$ biology subjects is suitable for use based on the evaluation of the quality of the E-module by language experts, module experts and media experts at 78.7\%,80\% and $86 \%$ with the following criteria: "very decent" totality. During the limited trial, the students responded by $85 \%$, while in the broad trial, the students responded by $86 \%$ and $88 \%$, and the biology subject educators responded by $92 \%$. Based on the results of this study, it can be concluded that the Lampung local 
wisdom E-module based on contextual teaching and learning for class $X$ biology subjects is valid and practical to be used and utilized in learning at SMA Negeri 1 Sumberjaya.

\section{Keywords: Contextual Teaching and Learning, E-modules, Local Wisdom}

\section{PENDAHULUAN}

Proses pembelajaran memerlukan dukungan komponen pembelajaran berupa model pembelajaran, strategi pembelajaran, metode, dan bahan ajar yang tepat guna mendukung tercapainya tujuan. Sesuai surat edaran Kemendikbud Nomor 4 Tahun 2020 tentang Pelaksanaan Kebijakan dalam Masa Darurat Penyebaran Corona Virus Disease (COVID-19), pada point 2a yaitu belajar dari rumah yang dilaksanakan untuk memberikan pengalaman belajar bermakna tanpa terbebani tuntutan menuntaskan pencapaian kurikulum untuk kenaikan kelas atau kelulusan. Salah satu model pembelajaran yang bermakna dalam situasi ini yaitu pembelajaran daring (Sadikin \& Hamidah, 2020, p. 111).

Konsekuensi dari pandemi ini perlu adanya perubahan sistem pembelajaran, seperti pembelajaran offline menjadi pembelajaran online, agar proses pembelajaran dapat terus berlanjut (Sintema, 2020, p. 3). Hal itu juga berdampak pada guru dan pengembang pendidikan untuk merubah pola pembelajaran serta menyediakan bahan belajar dan mengajar peserta didik secara langsung melalui alat digital secara jarak jauh (Fitriyani, Fauzi \& Sari 2020, p.166). Penting adanya media pembelajaran untuk mendukung pembelajaran daring yang digunakan peserta didik secara mandiri dan menjaga semangat belajar peserta didik (Hirzan \& Yuhendri, 2020, p. 143). Berdasarkan paparan di atas pada kesempatan ini peneliti memutuskan untuk mengembangkan bahan ajar dalam bentuk elektronik yaitu E-modul. Emodul dapat diartikan bahan ajar mandiri yang disusun sedemikian rupa kedalam satuan unit pembelajaran tertentu dalam format elektronik, adanya tautan link yang dihubungkan dengan setiap kegiatan pembelajaran sebagai navigasi menjadikan pengguna lebih interaktif, dilengkapi video, animasi dan audio untuk menambah pengetahuan pengguna (Kementrian Pendidikan dan Kebudayaan RI, 2017, p. 3). E-modul merupakan sumber belajar yang memuat metode, materi, batasan-batasan dan cara mengevaluasi yang sudah dirancang secara sistematis dan menarik untuk mencapai tujuan kompetensi berdasarkan kurikulum secara elektronik (Laili, 2019, p. 309). E-modul merupakan bahan ajar yang efektif untuk mempengaruhi hasil belajar peserta didik (Ricu Sidiq \& Najuah, 2020, p. 3). E-modul memiliki karakteristik untuk mencapai tujuan pembelajaran yaitu (1) self instructional, peserta didik dapat belajar sendiri tanpa bantuan orang lain atau pihak manapun, (2) self contained, satu E-modul terdapat satu materi pembelajaran agar peserta didik belajar secara tuntas, (3) stand alone, E-modul tidak bergantung pada sumber lain karena materi dan tugas menyatu, (4) adaptif, memiliki sifat adaptasi dalam perkembangan ilmu dan teknologi, (5) user friendly, E-modul mudah dipahami karena memiliki bahasa yang mudah dipahami dan sederhana digunakan, (6) konsistensi dalam font, spasi dan tata letak, (7) disajikan menggunakan media elektronik berbasis computer dan smarthphone, (8) multimedia, (9) memakai berbagai fitur pada aplikasi software, dan (10) memerlukan kecermatan dalam mendesain (Kementrian Pendidikan dan Kebudayaan RI, 2017, p. 3).

Berdasarkan prapenelitian yang dilakukan melalui observasi dan wawancara terhadap guru mata pelajaran biologi di SMA Negeri 1 Sumberjaya ditemukan permasalahan yaitu: 1) 
kurangnya motivasi belajar daring peserta didik akibat bahan ajar berupa buku paket, 2) guru mata pelajaran biologi belum pernah mengembangkan E-modul berbasis contextual teaching and learning, 3) kurang mengaitkan contoh pengaplikasian materi dengan kehidupan nyata, 4) belum adanya bahan ajar yang dapat membuat peserta didik menyadari potensi lokal dan budaya sekitar seperti kearifan lokal, 5) Hasil belajar peserta didik materi ekosistem dalam kategori rendah. Hasil belajar materi ekosistem kelas $\mathrm{X}$ dapat dilihat dari nilai rata-rata ulangan harian, dimana peserta didik kelas X MIPA 1 sampai 3 tahun ajaran 2019/2020 hanya $27,36 \%$ atau 26 orang memperoleh nilai di atas KKM dan 72,64\% atau 66 orang memperoleh nilai di bawah KKM. Hal tersebut menggambarkan bahwa rendahnya hasil belajar peserta didik kelas X SMA Negeri 1 Sumberjaya. Kriteria ketuntasan minimal (KKM) yang dituntut sekolah yaitu 6 (tuntas).

Materi ekosistem sangat cocok untuk dimasukan kedalam E-modul karena peserta didik memiliki hubungan erat dengan lingkungan sekitarnya. Selain itu, materi ekosistem dipadukan dengan kearifan lokal untuk mengkoordinir esensi kurikulum 2013, yaitu proses pembelajaran tidak hanya dirancang untuk menambah pengetahuan peserta didik, tetapi juga membekali peserta didik dengan keterampilan dan karakter yang luhur berdasarkan kepribadian bangsa Indonesia (Khusna et al., 2018, p. 48). Makhluk hidup akan mempengaruhi tatanan lingkungan hidup begitu pula sebaliknya (Retno Widjajanti, 2007, p. 123). Kesempatan ini, peneliti memanfaatkan materi ekosistem yang disisipkan dalam Emodul kearifan lokal agar peserta didik mengetahui potensi lokal daerah sekitar dan menumbuhkan sikap untuk menjaga alam sekitarnya. Didukung pula dengan pendapat (Saihu, 2019, p.69) yaitu Filosofi Tri Hita Karana atau tiga penyebab kesejahteraan yaitu menjalin hubungan baik dengan Tuhan atau parahyangan, menjalin hubungan baik dengan sesama manusia atau pawongan, menjalin hubungan baik dengan alam semesta atau palemahan. Bahkan karena begitu penting kearifan lokal butuh dikenalkan sejak dini, melalui keluarga terlebih dahulu lalu akan dilanjutkan kejenjang pendidikan. Penyisipan kearifan lokal dalam bahan ajar menjadikan media atau cara untuk melestarikan budaya setempat dan menciptakan masyarakat yang peduli lingkungan serta melestarikan lingkungan setempat.

Berdasarkan hal tersebut maka meyakinkan peneliti untuk melakukan suatu pengembangan produk berupa E-modul yang dapat mengurangi permasalahan tersebut dan dapat membantu peserta didik dalam meningkatkan pemahaman materi mata pelajaran biologi. Salah satunya yaitu E-modul yang berbasis kearifan lokal dan dikombinasikan bersama model pembelajaran sehingga membantu dalam permasalahan pembelajaran daring peserta didik. Setelah dilakukan pengkajian maka terpilihlah model pembelajaran contextual teaching and learning yang dapat menjawab permasalahan yaitu peserta didik sepenuhnya dilibatkan dalam menemukan materi yang akan dihubungkan dalam kehidupan nyata sehingga mendorong peserta didik menerapkan dalam kehidupannya (Wina Sanjaya, 2006, 225). Agar tercapainya proses pembelajaran yang ideal berdasarkan kurikulum 2013 yang berbasis kontekstual serta dapat meningkatkan hasil belajar peserta didik (Nadia Ramadhanty, Desnita, Asrizal, 2020, p. 420). Selaras dengan pernyataan (Martinis Yamin, 2007, p. 27) bahwa dalam sintaks contextual teaching and learning terdapat aspek berupa kontruktivisme yang berarti pengalaman peserta didik dijadikan proses membangun dan menyusun pengetahuan baru untuk struktur kognitif peserta didik. Pengetahuan memang berasal dari luar tetapi dapat dikontruksi oleh diri sendiri, sehingga mendapatkan perubahan dalam diri peserta didik. 
Sekolah dapat dikatakan lembaga pendidikan untuk melestarikan daerah sekitar dalam melaksanakan kegiatan pembelajaran. Tujuan penelitian ini adalah (1) Mengetahui cara pengembangan E-modul kearifan lokal Lampung Barat berbasis Contextual Teaching and Learning kelas X mata pelajaran biologi, (2) Mengetahui kelayakan E-modul kearifan lokal Lampung Barat berbasis Contextual Teaching and Learning kelas X mata pelajaran biologi.

\section{METODE PENELITIAN}

Penelitian ini merupakan penelitian dan pengembangan R\&D (Research and Development). Penelitian ini dilakukan untuk mengembangkan produk berupa E-modul kearifan lokal Lampung Barat berbasis contextual teaching and learning dalam bentuk aplikasi smarthphone yang di akses secara offline. Dilaksanakan pada bulan Maret tahun 2021 sampai dengan selesai, di SMA Negeri 1 Sumberjaya Provinsi Lampung Barat. Subjek penelitian terdiri dari pakar media, pakar materi, pakar bahasa, guru mata pelajaran biologi SMA Negeri 1 Sumberjaya, 10 peserta didik kelas X MIPA 1 SMA Negeri 1 Sumberjaya dan 62 peserta didik kelas X MIPA 2 dan 3 SMA Negeri 1 Sumberjaya.

Prosedur penelitian dan pengembangan yang digunakan mengacu pada desain $R \& D$ (Research and Development) yang dikembangkan oleh Borg and Gall yaitu terdiri dari 10 langkah tetapi disederhanakan menjadi 7 langkah karena keterbatasan waktu dan biaya. Penyederhanaan langkah ini didukung oleh pendapat Borg and Gall, mengenai penelitian pengembangan membutuhkan sumber daya yang substansial maka kemungkinan kecil untuk mahasiswa strata satu mendapat dukungan finansial dan anggota dalam menyelesaikan produknya, sehingga langkah terbaik agar produk tetap berjalan yaitu dengan cara menyederhanakan penelitian sampai tahap ketujuh tanpa mengurangi nilai penelitian dan pengembangan itu sendiri (Borg and Gall, 2003, p. 569). Keterbatasan tersebut yaitu anggaran, waktu dan kemampuan peneliti (Masykur et al., 2017, p. 177). Sehingga, peneliti hanya melakukan penelitian pengembangan sampai tahap ke tujuh yaitu menentukan kelayakan E-modul berdasarkan kepada hasil validasi ahli, respon guru dan respon peserta didik. Langkah-langkah tersebut yaitu:

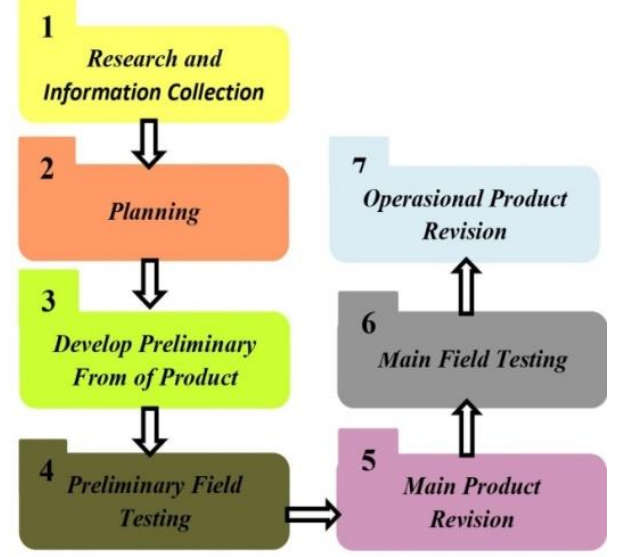

Gambar 1. Langkah-langkah Penelitian Pengembangan Borg and Gall

(1) Research and Information Collection, mengidentifikasi potensi dan masalah (2) Planning, perecanaan penelitian berupa tujuan penelitian, memperkirakan (tenaga, biaya dan waktu), perencanaan bentuk produk serta kelompok yang dilibatkan dalam penelitian (3) Develop Preliminary From of Product, membuat desain pengembangan produk (4) 
Preliminary Field Testing, setelah produk selesai maka dilakukan uji pendahuluan atau terbatas yaitu validasi produk oleh pakar media, pakar materi, pakar bahasa, peserta didik dan guru (5) Main Product Revision, melakukan revisi produk setelah dilakukan validasi oleh para ahli (6) Main Field Testing, uji secara luas yaitu penyebaran angket kepada guru dan peserta didik untuk melihat respon peserta didik terhadap produk (7) Operasional Product Revision, revisi produk berdasarkan uji coba secara luas sehingga akan dihasilkan produk berupa Emodul kearifan lokal Lampung berbasis contextual teaching and learning (Haviz, 2016, p. 29). Teknik pengumpulan data pada penelitian ini menggunakan instrumen berupa angket validasi para ahli, angket respon guru dan peserta didik. Teknik analisis data menggunakan data kuantitatif dan kualititaif. Teknik analisis data validasi angket menggunakan skala perhitungan penelitian pengembangan untuk perhitungan kuantitatif, dengan demikian jawaban diberi skor sebagai berikut.

Tabel 1. Skala Likert

\begin{tabular}{ccc}
\hline Kategori & Skor & Presentasi \\
\hline Sangat Baik (SB) & 5 & $85-100 \%$ \\
Baik (B) & 4 & $69-84 \%$ \\
Kurang Baik (KB) & 3 & $53-68 \%$ \\
Tidak Baik (TB) & 2 & $37-52 \%$ \\
Sangat Tidak Baik (STB) & 1 & $20-39 \%$ \\
\hline
\end{tabular}

Sumber:(Sugiyono, 2017, p.135)

Uji validitas produk diperoleh berdasarkan hasil validasi instrumen ahli media, ahli materi dan ahli bahasa. Data hasil validasi dapat dianalisis menggunakan rumus sebagai berikut:

$$
P_{S}=\frac{S}{N} \mathrm{X} 100 \%
$$

Keterangan:

Ps $\quad=$ Persentase skor

$\mathrm{S} \quad=$ Skor yang diperoleh

$\mathrm{N} \quad=$ Jumlah skor maksimum

Setelah data diperoleh kemudian diinterpretasikan kedalam kategori kelayakan produk sebagai berikut:

Tabel 2. Kriteria Kelayakan

\begin{tabular}{cc}
\hline Skor Rata-rata & Kategori \\
\hline$<21 \%$ & Tidak Layak \\
$21 \%-40 \%$ & Kurang Layak \\
$41 \%-60 \%$ & Cukup Layak \\
$61 \%-80 \%$ & Layak \\
$81 \%-100 \%$ & Sangat Layak \\
\hline \multicolumn{2}{l}{ Sumber: (AnasSudjiono, 2012, p.43) }
\end{tabular}

E-modul kearifan lokal Lampung berbasis contextual teaching and learning kelas $\mathrm{X}$ mata pelajaran biologi dinyatakan valid secara teoritis jika persentase kelayakannya adalah $\geq 61 \%$. 


\section{HASIL DAN PEMBAHASAN}

Produk yang dihasilkan penelitian pengembangan ini berupa E-modul kearifan lokal berbasis contextual teaching and learning berbentuk aplikasi smarthphone yang dapat diakses secara offline. Langkah awal penelitian adalah studi pendahuluan, hasil studi pendahuluan menunjukan bahwa potensi yang dimiliki SMA Negeri 1 Sumberjaya cukup mumpuni dalam hal sarana dan prasarana, tetapi sarana dan prasarana yang ada tidak dimanfaatkan dengan maximal. Identifikasi masalah dilakukan melalui observasi, wawancara dan analisis kebutuhan. Berdasarkan hasil wawancara dan observasi yang telah dilakukan, diperoleh masalah yang mendasar yaitu dalam proses pembelajaran jarak jauh peserta didik dan guru menggunakan bahan ajar berupa buku paket yang dibagikan oleh sekolah dan video dari youtube. Buku paket membantu peserta didik dalam memahami dan mendalami, namun jika digunakan dari tahun ketahun akan berdampak pada proses perkembangan pengetahuan peserta didik. Terdapat gambar dalam buku paket namun tidak berwarna dan pembahasan materi untuk beberapa pokok bergabung dalam satu buku paket sehingga membuat peserta didik malas untuk membaca dan mengurangi ketertarikan peserta didik. Buku paket berisikan materi yang bersifat umum terkesan kurang adanya keterkaitan dengan kehidupan sehari-hari seperti pengaplikasian materi masih kurang mengaitkan dengan kehidupan nyata, tidak adanya bahan ajar yang berbasis kearifan lokal yang membuat peserta didik kurang menyadari potensi lokal dan budaya sekitarnya dan bahan ajar yang membuat peserta didik kurang menarik membuat motivasi belajar peserta didik berkurang. Permasalahan tersebut akan berdampak pada nilai akhir peserta didik, seperti nilai ulangan harian masih tergolong rendah. Sehingga peneliti mengembangkan bahan ajar berupa E-modul kearifan lokal Lampung berbasis contextual teaching and learning untuk membantu pembelajaran daring. Mengaitkan kearifan lokal dalam E-modul yaitu menghadirkan lingkungan sekitar peserta didik pada kegiatan pembelajaran. Seperti yang dijelaskan oleh Daroe Iswatiningsih yaitu budaya kearifan lokal perlu dikenalkan dan diajarkan di dunia pendidikan terutama sekolah agar menumbuhkan sikap cinta pada budaya (Iswatiningsih, 2019, p. 157).

Langkah kedua merupakan perencanaan pengembangan E-modul kearifan lokal Lampung Barat berbasis contextual teaching and learning dimulai dari pengumpulan referensi materi ekosistem dari buku Campbell dan buku sains lain agar materi sistematis, praktis, singkat, padat, jelas dan menyesuaikan dengan kearifan lokal. Selanjutnya perencanaan desain E-modul menggunakan Adobe Photoshop, dibuat menggunakan Microsoft Word dan berbentuk aplikasi yang dikembangkan menggunakan program IDE (Integrated Development Enviroment) android studio. Konten media yang akan dikembangkan dibuat semenarik mungkin dan memudahkan penggunanya baik guru maupun peserta didik. Segi bahasa menggunakan bahasa yang baik sesuai dengan Pedoman Umum Ejaan Bahasa Indonesia (PUEBI), komunikatif dan mudah dipahami oleh pengguna. Selaras dengan itu Yenner dkk menyatakan, bahan ajar yang baik adalah bahan ajar yang menyajikan empat point penting yaitu kemampuan berbahasa pelajar, kaidah bahasa, pilihan kata dan keterbacaan (Kapitan, Harsiati \& Basuki 2018, p. 100).

Langkah ketiga pengembangan desain produk pemilihan gambar cover bertemakan ekosistem lokal Lampung Barat, mendesain bagian isi bernuansa khas lokal Lampung Barat, mendesain gambar dengan tampilan warna yang kontras. Mendesain menu dengan tujuan mempermudah pengguna dan menyesuaikan dengan yang dibutuhkan pengguna. Setelah 
produk E-modul didesain, maka dilakukan pemeriksaan ulang guna memastikan produk berjalan dengan baik saat digunakan. Kemudian tahap selanjutnya yaitu validasi para ahli seperti pakar media, pakar materi, pakar bahasa, guru dan peserta didik. Uji coba produk dilakukan pada uji coba pendahuluan atau terbatas dan uji coba secara luas. Adapun hasil tersebut disajikan pada tabel 3.

Tabel 3. Hasil Uji Coba Kelayakan Produk

\begin{tabular}{ccc}
\hline Subjek Uji Coba & Kelayakan(\%) & Ket. \\
\hline Ahli Media & $86 \%$ & Sangat Layak \\
Ahli Materi & $80 \%$ & Layak \\
Ahli Bahasa & $78,7 \%$ & Layak \\
Uji Coba Terbatas & $85 \%$ & Sangat Layak \\
Uji Coba Luas Guru & $87 \%$ & Sangat Layak \\
Uji Coba Luas Peserta didik & $92 \%$ & Sangat Layak \\
\hline
\end{tabular}

E-modul kearifan lokal Lampung berbasis contextual teaching and learning kelas X mata pelajaran biologi dinyatakan valid dan praktis secara teoritis karena persentase kelayakannya adalah $\geq 61 \%$

Tabel 4. Hasil Validasi Produk Oleh Para Pakar

\begin{tabular}{|c|c|}
\hline Validator & Hasil Validasi \\
\hline L ID (Ahli Media) & $\begin{array}{l}\text { Instrumen yang digunakan untuk uji coba pakar media berupa } \\
\text { angket. Setelah angket disebar, data pada angket diolah sehingga } \\
\text { memperoleh hasil analisis data ahli media sebelum revisi sebesar } \\
52 \% \text { dengan kriteria cukup layak dan setelah revisi sebesar } 86 \% \\
\text { dengan kriteria sangat layak. }\end{array}$ \\
\hline L EK (Ahli Materi) & $\begin{array}{l}\text { Instrumen yang digunakan untuk uji coba pakar materi berupa } \\
\text { angket. Setelah angket disebar, data pada angket diolah sehingga } \\
\text { memperoleh hasil analisis data pakar materi sebesar } 80 \% \text { dengan } \\
\text { kriteria layak dan dapat digunakan setelah melakukan revisi dari } \\
\text { saran dan komentar yang diberikan seperti penambahan indikator } \\
\text { kearifan lokal Lampung Barat pada indikator yaitu penambahan } \\
\text { indikator mengidentifikasi peran masyarakat Lampung Barat dalam } \\
\text { menjaga kearifan lokal dan penambahan video contoh kearifan lokal } \\
\text { Lampung Barat yaitu video Hajat Uwar }\end{array}$ \\
\hline L UN (Ahli Bahasa) & $\begin{array}{l}\text { Instrumen yang digunakan untuk uji coba pakar bahasa berupa } \\
\text { angket. Setelah angket disebar, data pada angket diolah sehingga } \\
\text { memperoleh hasil analisis data ahli bahasa sebesar } 78,7 \% \text { dengan } \\
\text { kriteria layak dan dapat digunakan tanpa perbaikan. }\end{array}$ \\
\hline
\end{tabular}

Kemudian saran dan komentar yang diberikan dijadikan untuk menyempurnakan desain produk awal seperti pada tabel berikut ini:

Tabel 5.

Hasil Perbandingan Sebelum dan Sesudah Revisi Pada Validasi Ahli Media

$\begin{array}{ccc}\text { Validator } & \begin{array}{c}\text { Catan } \\ \text { Validator }\end{array} & \text { Hasil Perbandingan Tampilan Sebelum dan } \\ \text { Sesudah Revisi Ahli Media }\end{array}$




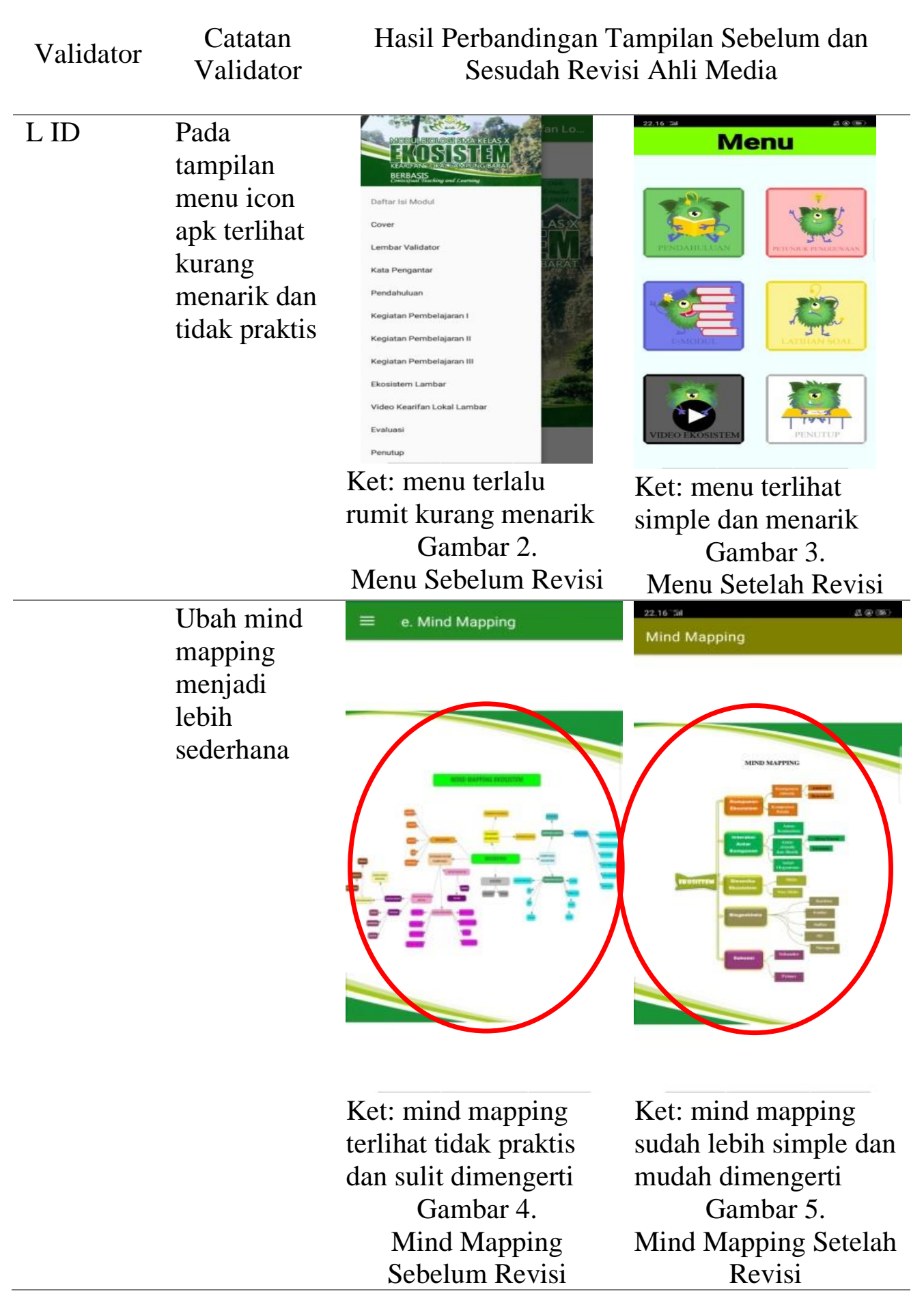




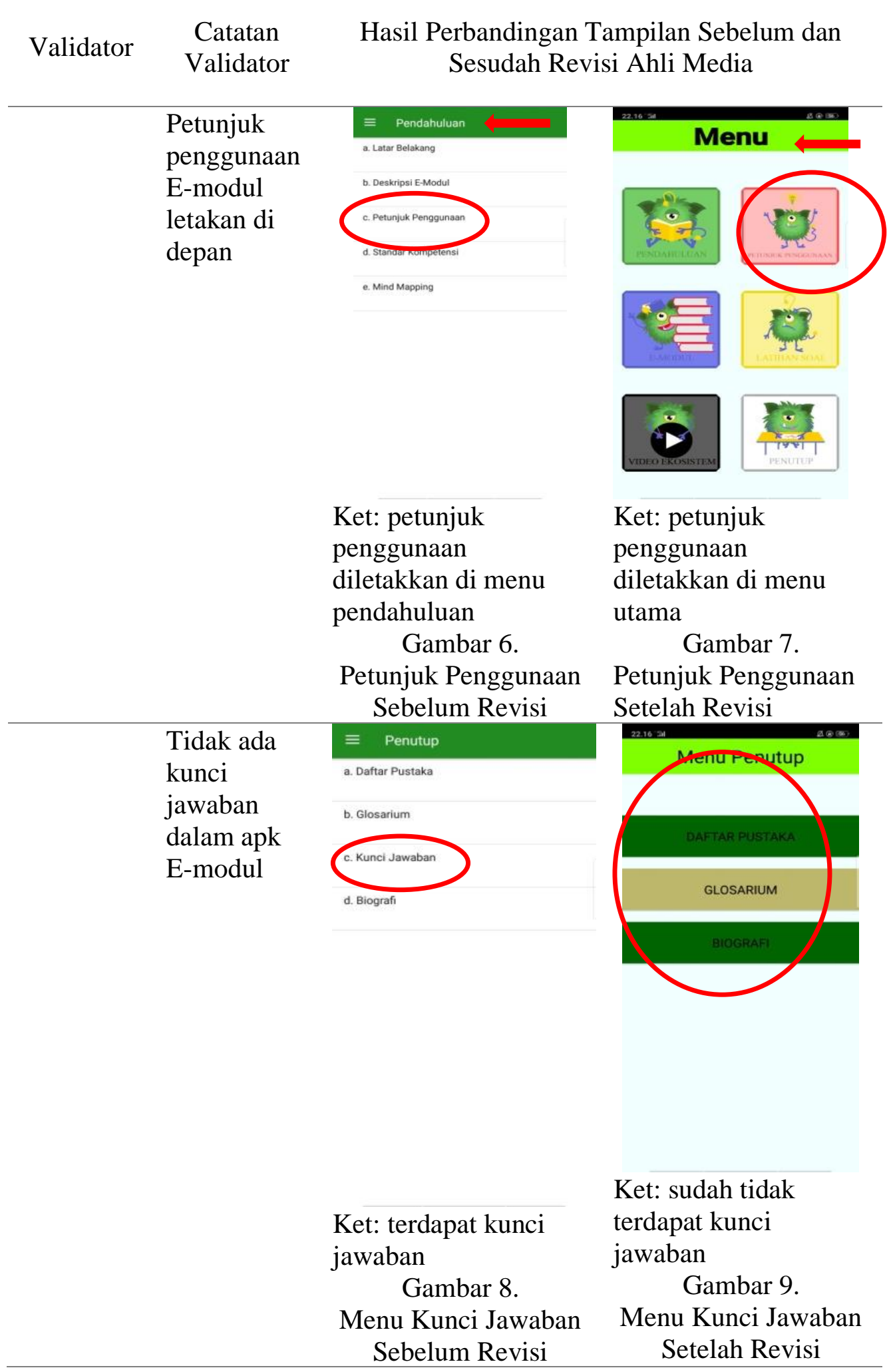

Tabel 6.

Perbaikan dan Hasil Perbandingan Tampilan Sesudah dan Sebelum Revisi Berdasarkan Saran Ahli Materi 


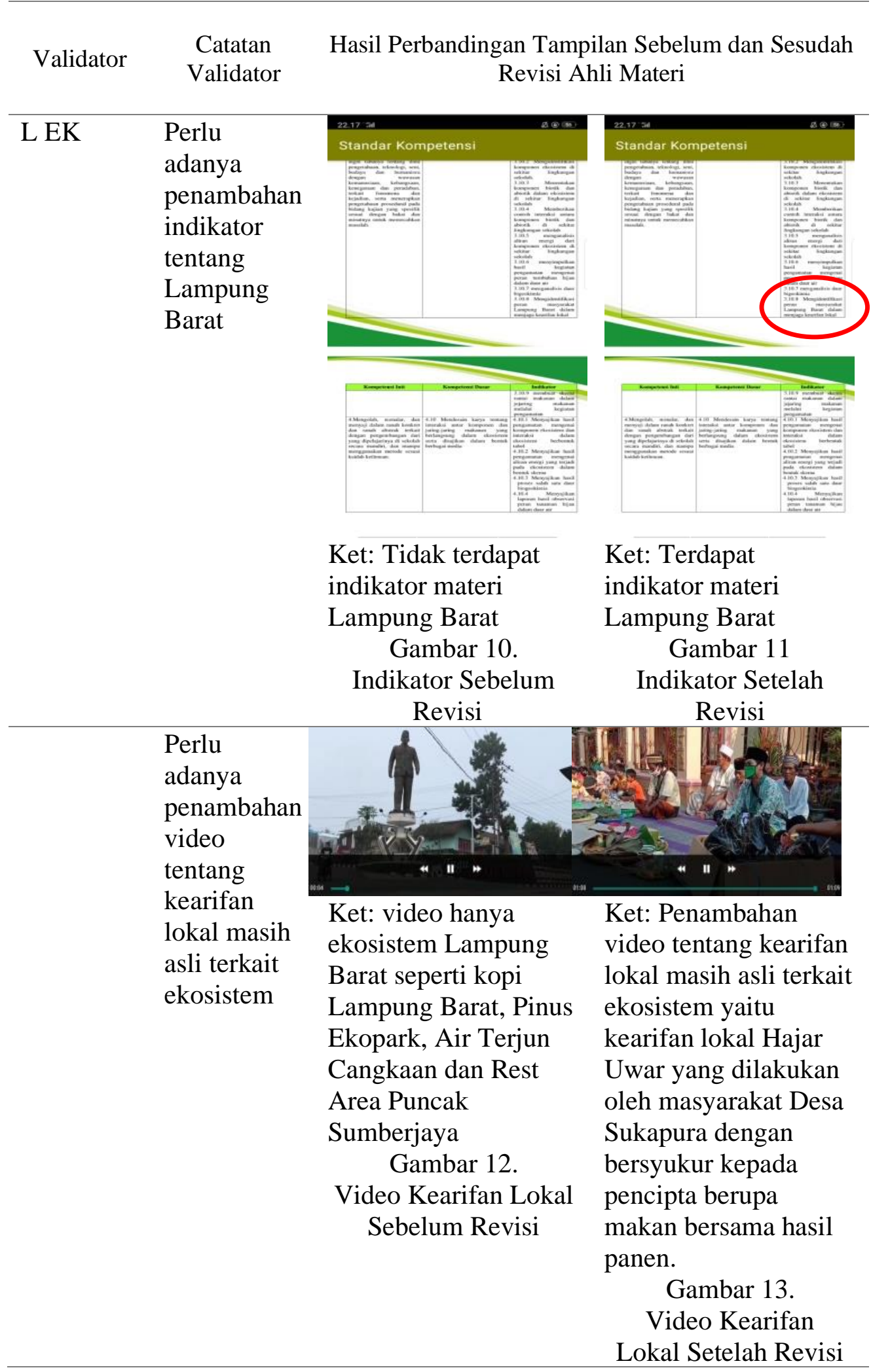

Setelah produk pengembangan E-modul divalidasi oleh pakar media, pakar materi dan pakar bahasa serta diperoleh hasil dengan kategori layak digunakan dalam proses pembelajaran, maka tahap selanjutnya yaitu melakukan uji coba pada peserta didik dan guru. Uji coba yang pertama yaitu uji coba terbatas yang dilakukan kepada 10 peserta didik kelas X MIPA 1 SMA Negeri 1 Sumberjaya dengan memperoleh hasil analisis sebesar $85 \%$ dan berdasarkan kriteria kelayakan produk penggunaan media maka dapat diinterprestasikan 
bahwa E-modul yang telah dikembangkan termasuk dalam kategori sangat layak dan dapat digunakan tanpa perbaikan.

Setelah selesai melakukan uji coba produk secara terbatas, E-modul yang dikembangakan dalam penelitian ini selanjutnya tahap uji coba secara luas. Uji coba produk secara luas dilaksanakan oleh 62 peserta didik SMA Negeri 1 Sumberjaya, dimana 30 peserta didik MIPA 2 dilakukan secara daring menggunakan google form dan 32 peserta didik MIPA 3 dilakukan secara luring di sekolah yang masing-masing memperoleh hasil analisis sebesar $86 \%$ dan $88 \%$ dan berdasarkan kriteria kelayakan produk penggunaan media maka dapat diinterprestasikan bahwa E-modul yang telah dikembangkan termasuk dalam kategori sangat layak dan dapat digunakan tanpa perbaikan. Selanjutnya dilaksanakan oleh guru mata pelajaran biologi yaitu P SN yang memperoleh hasil analisis data sebesar $92 \%$ dan berdasarkan kriteria kelayakan produk maka dapat diinterprestasikan bahwa E-modul yang telah dikembangkan termasuk dalam kategori sangat layak dan dapat digunakan tanpa perbaikan. Sehingga E-modul valid dan praktis digunakan dalam proses pembelajaran karena validasi produk, tanggapan guru dan peserta didik memperoleh persentase kelayakan menggunakan teknik statistic deskriptif dalam mengukur standar kelayakan E-modul pembelajaran biologi adalah media pembelajaran dikatakan valid dan praktis apabila memperoleh persentase diatas batas minimum $>61 \%$.

Produk akhir yang dihasilkan dalam penelitian pengembangan adalah bahan ajar mata pelajaran biologi berupa aplikasi E-modul kearifan lokal Lampung Barat berbasis contextual teaching and learning. Melalui revisi-revisi sesuai saran dan komentar ahli media, ahli bahasa dan ahli materi. Berikut merupakan kajian produk akhir:

Tabel 7.Kajian Produk Akhir

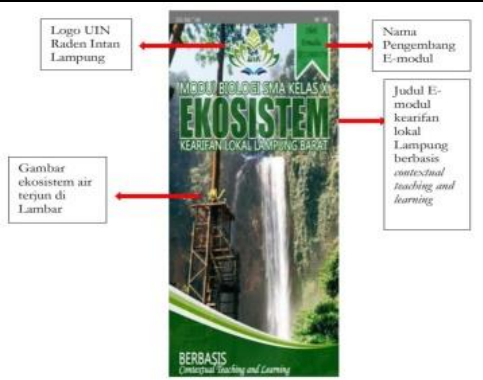

Gambar 14. Tampilan Akhir Menu Pembuka

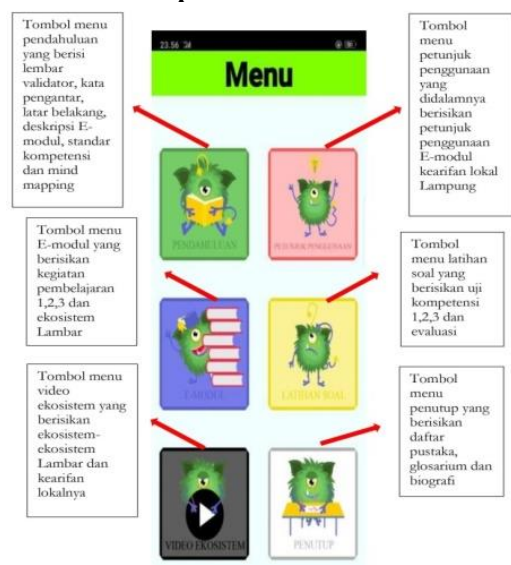

Gambar 15. Tampilan Akhir Halaman Menu Utama 


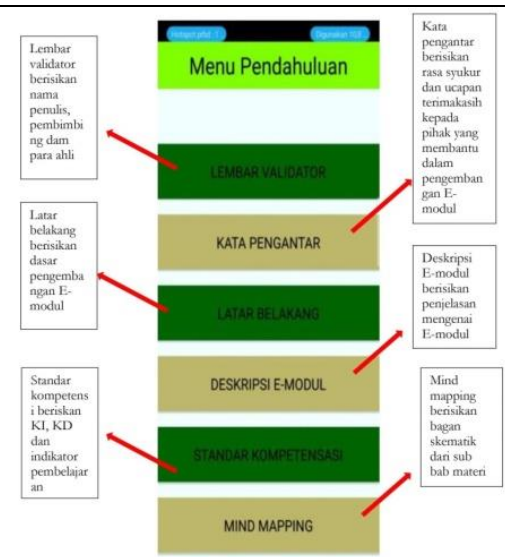

Gambar 16. Tampilan Akhir Menu Pendahuluan
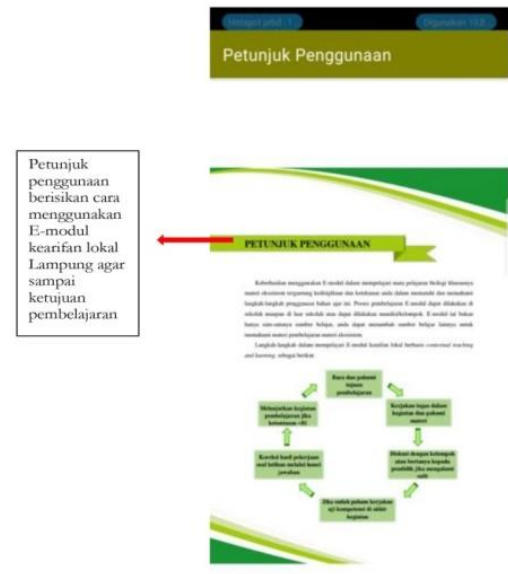

Gambar 17. Tampilan Akhir Halaman Menu Penggunaan

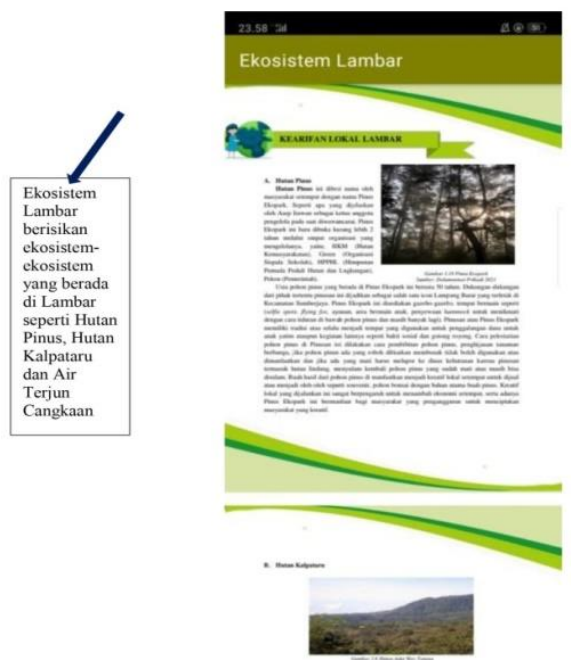

Gambar 18. Tampilan Akhir Menu Ekosistem Lambar 


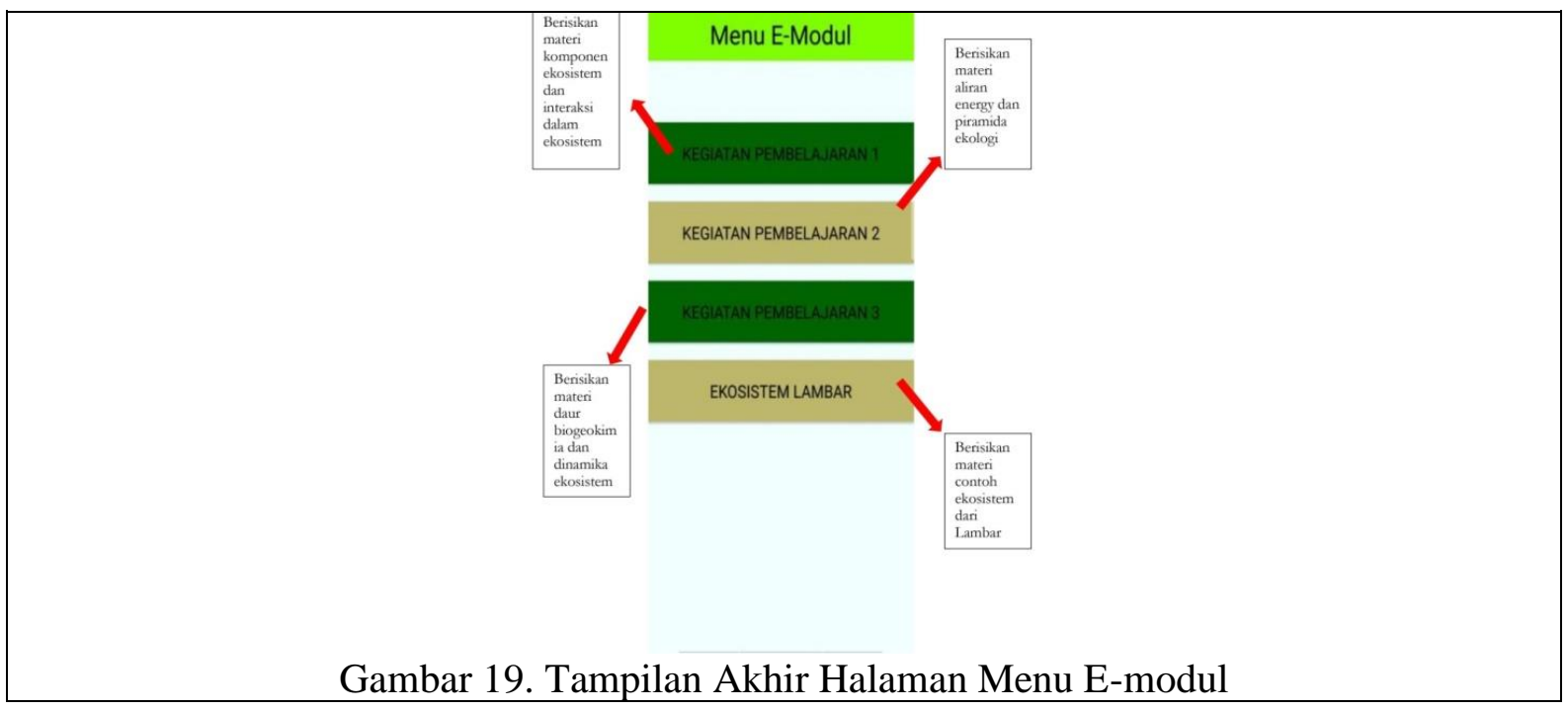

Pada gambar 14 terdapat peneliti desain dengan tampilan yang menarik, berwarna dan gambar cover sesuai dengan materi ekosistem. Pemakaian cover dengan gambar air terjun Bangkuang yang merupakan salah satu ekosistem di Lampung Barat. Gambar 15 dapat mengantarkan pengguna ke menu utama, seperti: menu pendahuluan, petunjuk penggunaan, E-modul, latihan soal, video ekosistem dan penutup. Gambar 16 terdapat sub menu yang terdiri dari latar belakang, deskripsi E-modul, petunjuk penggunaan, standar kompetensi dan mind mapping. Gambar 17 berisikan penjelasan mengenai petunjuk penggunaan E-modul untuk melakukan proses pembelajaran, dengan harapan peserta didik memahami cara menggunakan modul sehingga pembelajaran berjalan lancar dan sampai ketujuan pembelajaran. Gambar 18 berisikan contoh ekosistem lokal dari daerah lokal Lampung yang ada di Lampung Barat. Gambar 19 terdapat kegiatan pembelajaran 1 sampai 3 dan ekosistem Lampung Barat.

\section{SIMPULAN}

Berdasarkan hasil penelitian dan pengembangan yang telah dilakukan di lapangan maka dapat disimpulkan dalam beberapa hal yaitu: Pengembangan E-modul kearifan lokal Lampung berbasis contextual teaching and learning kelas $\mathrm{X}$ mata pelajaran biologi dikembangkan menggunakan program IDE (Integrated Development Enviroment) android strudio, dikombinasikan dengan aplikasi microsoft word dan Adobe Photoshop serta dapat diakses melalui smartphone secara offline. Kelayakan yang didapat dari hasil validasi para ahli yaitu ahli media sebesar $86 \%$ dengan kriteria sangat layak, ahli materi $80 \%$ dengan kriteria layak, ahli bahasa 78,7\% dengan kriteria layak, peserta didik saat uji coba terbatas sebesar $85 \%$ dengan kriteria sangat layak, saat uji coba secara luas peserta didik memperoleh sebesar $86 \%$ dan $88 \%$ dengan kriteria sangat layak dan pendidik saat sebesar $92 \%$ dengan kriteria sangat layak. Berdasarkan hasil analisis data yang diperoleh, E-modul kearifan lokal Lampung berbasis contextual teaching and learning dinyatakan valid dan praktis untuk digunaan saat proses pembelajaran. Rekomendasi R\&D masih perlu ditindaklanjuti sampai efektifitasnya agar diperoleh produk media pembelajaran yang layak dan lebih berkualitas saat digunakan untuk pembelajaran. 


\section{DAFTAR PUSTAKA}

Anas Sudjiono. (2012). Pengantar Statistic. RajawaliPers.

Borg and Gall. (2003). Educational Research An Introduction (ed. Tujuh). Allyn and Bacon.

Fitriyani, Y., Fauzi, I., \& Sari, M. Z. (2020). Motivasi Belajar Mahasiswa Pada Pembelajaran

Daring Selama Pandemik Covid-19. Profesi Pendidikan Dasar, 7(1), 121-132. https://doi.org/10.23917/ppd.v7i1.10973

Haviz, M. (2016). Research and Development; Penelitian Di Bidang Kependidikan Yang Inovatif, Produktif dan Bermakna. Ta'dib, 16(1). https://doi.org/10.31958/jt.v16i1.235

Hirzan, L., \& Yuhendri, M. (2020). Pengembangan E-Modul Mata Pelajaran Instalasi Penerangan Listrik untuk Pembelajaran Daring. Jurnal Pendidikan Teknik Elektro, 01(01), 142-146. http://jpte.ppj.unp.ac.id/index.php/JPTE/article/view/58

Iswatiningsih, D. (2019). Penguatan Pendidikan Karakter Berbasis Nilai-Nilai Kearifan Lokal di Sekolah. Jurnal Satwika, 3(2), 155. https://doi.org/10.22219/satwika.vol3.no2.155164

Kapitan, Y. J., Harsiati, T., \& Basuki, I. A. (2018). Pengembangan Bahan Ajar Menulis Teks Cerita Fantasi Bermuatan Nilai Pendidikan Karakter di Kelas VII. Jurnal Pendidikan, 3(1), 100-106. http://journal.um.ac.id/index.php/jptpp/

Kementrian Pendidikan dan Kebudayaan RI. (2017). Panduan Praktis Penyusunan E-Modul Pembelajaran (D. P. D. dan M. Direktorat Pembinaan SMA (ed.)). DPSMA.

Khusna, N., Shufa, F., \& Artikel, S. (2018). Pembelajaran Berbasis Kearifan Lokal Di Sekolah Dasar: Sebuah Kerangka Konseptual. Jurnal Ilmiah Kependidikan, 1(1), 48-53. http://jurnal.umk.ac.id/index.php/pendas/index

Laili, I. (2019). Efektivitas Pengembangan E-Modul Project Based Learning Pada Mata Pelajaran Instalasi. Jurnal Imiah Pendidikan Dan Pembelajaran, 3, 306-315. https://ejournal.undiksha.ac.id/index.php/JIPP/article/download/21840/13513

Martinis Yamin. (2007). Profesionalisasi Guru \& Implementasi KTSP. Gaung Persada Press.

Masykur, R., Nofrizal, N., \& Syazali, M. (2017). Pengembangan Media Pembelajaran Matematika dengan Macromedia Flash. Al-Jabar : Jurnal Pendidikan Matematika, 8(2), 177. https://doi.org/10.24042/ajpm.v8i2.2014

Nadia Ramadhanty, Desnita, Asrizal, Y. D. (2020). Perbandingan Hasil Belajar Siswa Menggunakan E-Modul Newton Gravitasi Dan Usaha Energi Kelas X Sman 2 Padang Universitas Negeri Padang Staf Pengajar Jurusan Fisika, FMIPA Universitas Negeri Padang Keterangan Penulis 3. 13(3), 419-426. http://dx.doi.org/10.24036/9207171074

Retno Widjajanti. (2007). Ilmu Pengetahuan Alam. PT. Gelora Aksara Pratama.

Ricu Sidiq, \& Najuah. (2020). Pengembangan E-Modul Interaktif Berbasis Android pada Mata Kuliah Strategi Belajar Mengajar. Jurnal Pendidikan Sejarah, 9(1), 1-14. https://doi.org/10.21009/jps.091.01

Sadikin, A., \& Hamidah, A. (2020). Pembelajaran Daring di Tengah Wabah Covid-19. Biodik, 6(2), 109-119. https://doi.org/10.22437/bio.v6i2.9759

Saihu, S. (2019). Pendidikan Karakter Berbasis Kearifan Lokal (Studi Di Jembrana Bali). Edukasi Islami: Jurnal Pendidikan Islam, 69. https://doi.org/10.30868/ei.v8i01.364

Sintema, E. J. (2020). Effect of COVID-19 on the performance of grade 12 students: Implications for STEM education. Eurasia Journal of Mathematics, Science and Technology Education, 16(7), 1-6. https://doi.org/10.29333/EJMSTE/7893

Sugiyono. (2017). Metode Penelitian Pendidikan Pendekatan Kuantitatif, kualitatif, dan $R \& D$. Alfabeta.

Wina Sanjaya. (2006). Strategi Pembelajaran. Kencana Prenada Media Group. 